\title{
Analysis and trends of photo-trapping in Mexico: text mining in $\mathbf{R}$
}

Salvador ManduJano

${ }^{1}$ Red de Biología y Conservación de Vertebrados, Instituto de Ecología A.C., Km 2.5 Carretera Antigua Coatepec 351, El Haya, Xalapa 91070, Ver. México. E-mail: salvador.mandujano@inecol.mx

This paper gathers published studies that used photo-trapping as the primary or supplementary method to obtain data on mammal and bird species in Mexico. The aim is to determine temporal trends, scientific journals, species, research groups, regions, and key topics investigated using this technology. A secondary objective of this paper was to illustrate the usefulness of text mining tools to analyze and summarize relatively large amounts of information. Papers about photo-trapping in Mexico published in specialized journals and books from 1998 to 2017 were compiled from Google Scholar and processed with various packages in R. A total of 188 papers about photo-trapping in Mexico were compiled, with $\mathbf{8 8 . 2} \%$ published in 50 journals over the past seven years. The main journals were Therya, Revista Mexicana de Biodiversidad, Acta Zoologica Mexicana (New Series) and Revista de Biología Tropical. The articles identified were written by 406 co-authors, 28 of whom contributed with $32.4 \%$ of the papers published. A total of 40 species were reported in the title and abstract of these papers; the most frequent species were Panthera onca, Leopardus pardalis, Puma concolor, Tapirus bairdii, Tayassu pecari, Odocoileus virginianus, and Cuniculus paca. Oaxaca, Campeche, Sonora, Chiapas, Guanajuato, and Puebla were the main states where studies were conducted; in particular, most of them were carried out within Biosphere Reserves. Major research topics comprised records that broaden the distribution range, estimates of relative abundance and density, analysis of activity patterns, ecological interactions between species, and use of photo-trapping data as supplementary information to elaborate inventories of species. The analysis of text mining clearly indicates a trend towards an increasing use of photo-trapping in Mexico. Felines, ungulates and various species of the order Carnivora are main subjects of study. Photo-trapping has been used to explore a number of aspects of the biology of animal species. A large number of studies have been carried out in southeastern Mexico. The use of text mining techniques is a practical approach to analyze large volumes of data.

El objetivo del presente trabajo fue recopilar los estudios publicados donde se emplea el foto-trampeo como método principal o complementario para la obtención de datos de mamíferos y aves de talla mediana y grande en México, con la finalidad de conocer la tendencia temporal, revistas donde se publicó, especies, grupos de investigación, regiones y temas principales abordados con esta tecnología. Adicionalmente, como segundo propósito en este trabajo se ejemplifica la utilidad de las herramientas de minería de textos para analizar y sintetizar cantidades relativamente grandes de información. Se recopilaron libros, capítulos y artículos científicos publicados sobre foto-trampeo en México entre 1998 a 2017 en el Google Académico, y se procesaron a través de minería de textos con diferentes paquetes en R. Se encontraron 188 artículos sobre foto-trampeo en México de los cuales el 88.2 \% fue publicado en los últimos siete años. Los artículos fueron publicados en 50 revistas; destacan Therya, Revista Mexicana de Biodiversidad y Acta Zoológica Mexicana (nueva serie) y Revista de Biología Tropical. Los artículos fueron escritos por 406 coautores, de los cuales 28 han contribuido con el $32.4 \%$ de los trabajos publicados. Un total de 40 especies se reporta en el título y resumen de los documentos; de las cuales las más estudiadas fueron: Panthera onca, Leopardus pardalis, Puma concolor, Tapirus bairdii, Tayassu pecari, Odocoileus virginianus y Cuniculus paca. Oaxaca, Campeche, Sonora, Chiapas, Guanajuato y Puebla fueron los principales estados estudiados. En particular, destacan Reservas de la Biosfera. Los principales temas de investigación tratan sobre registros notables que amplían el rango de distribución geográfica de varias especies, diversidad, estimaciones de abundancia relativa y de la densidad de población utilizando captura-recaptura, análisis de patrones de actividad entre especies, e interacciones ecológicas. El análisis de minería de texto indica claramente que el foto-trampeo es un método en crecimiento en México. Los felinos, ungulados y varias especies del orden Carnívora, son los más frecuentemente estudiados. El foto-trampeo se ha empleado para conocer variados aspectos de la biología de las especies animales. La región del Sureste del país es donde se ha realizado un mayor número de estudios. El empleo de técnicas de minería de texto es una alternativa práctica para analizar volúmenes grandes de datos.

Key words: birds; camera-traps; journals; mammals; R; text mining; topic trend.

(C) 2019 Asociación Mexicana de Mastozoología, www.mastozoologiamexicana.org

\section{Introduction}

The monitoring of biodiversity, in either different regions or a single region through time, requires collecting data on many species, often across different taxonomic groups and trophic levels, and with different life histories and other parameters that add complexity to the investigation (O'Brien et al. 2010). In particular, inventories serve a number of purposes, such as determining the ecological diversity in a given site, making comparisons between sites, refining distribution maps for individual species, obtaining demographic parameters on populations, or assessing the impact of human activities on mammal communities
(Baillie et al. 2008). An in-depth knowledge of the fauna supports the development and planning of improved conservation strategies, particularly in protected natural areas (Bruner et al. 2001). In this sense, birds and medium-sized and large mammals are considered to be key groups to monitor biodiversity and the state of ecological integrity (Ahumada et al. 2011).

One of the most popular techniques to survey the fauna is based on cameras-traps, also called photo-trapping (Meek and Pittet 2012, McCallum 2013, Burton et al. 2015, Rowcliffe 2017). This is due, among several factors, to the improvement in technological development and the lower 
costs of the equipment involved (Rovero et al. 2013). The applications of this technique range from data collection for species inventories, the study of activity patterns, estimates of occupancy, the relative abundance and density of animals, up to more specific aspects such as behavior and interactions between species and their habitat, among other topics (Jenks et al. 2011). Photographs provide reliable records about the presence of species, and can be shared for verification by experts (O'Connell et al. 2010). The use and development of photo-trapping has been so successful that several books and manuals studies addressing it have been published in just a few years ( $\mathrm{O}^{\prime}$ Connell et al. 2010, Fleming et al. 2014, Rovero and Zimmermann, 2016, Wearn and Glover-Kapfer 2017). In Mexico, the use of camera traps has boomed, mainly in the past decade, being applied to several species with various objectives in different regions and habitats across the country. Hence, the trends and contributions of this technology to the knowledge of the fauna is a topic worth investigating.

One way to measure the overall and particular trends in the use of photo-trapping is data mining (text mining), as this approach facilitates the methodical analysis of large volumes of data. Specifically, text mining is the process of extracting information from a set of texts (Kwartler 2017). The results are displayed as tables and graphs that can be useful for multiple purposes (Silge and Robinson 2017). In a scientific context, for instance, text mining may contribute to a relatively rapid analytical processing of extensive information. Although text mining may not be a fully automated process in itself, the different computation tools currently available enable the processing of large amounts of text over a relatively short time. In particular, several packages have been developed for the $R$ platform that are useful to analyze this type of information (Kwartler 2017, Silge and Robinson 2017).

The main objective of this work was to gather published studies using photo-trapping as a primary or supplementary method to collect data or records on the presence of species in various locations in Mexico. The specific objectives were: 1) Analyze the temporal trend of studies. 2) Identify the species that are either most frequently studied or for which more information is obtained with this method. 3) Identify the main research groups, highlighting the research leaders. 4) Identify the sites, regions, and natural areas studied. 5) Assess whether the data from photo-trapping are being applied to specific management and conservation issues/solutions, in addition to the generation of scientific knowledge. 6) Suggest further topics in the application of photo-trapping in our country.

\section{Methods}

Information gathering. Published information was collected on studies reporting the use of camera-traps as the main or supplementary methodology to get information from a number of animal species. To this end, a comprehensive search of articles cited in the Google Scholar was conducted spanning from 1990 to late 2017. The search was con- ducted using the key words photo-trapping, camera-traps, monitoring, Mexico, in both Spanish and English. Excluded sources were technical reports, theses and website news. The respective literature references were saved in BibTex format (Mata-Perez 2014). The RefManageR package was used for managing the bibliography in BibTex format (McLean 2014, 2017). Once all the literature references were compiled, these were saved as files with the extension .bib and used as basis for the text mining analysis in $\mathrm{R}$. The quantitative analysis consisted basically in constructing frequency tables for each objective stated in this work using the packages tidyverse (Wickham 2017), tm (Feinerer and Hornik 2017), and ggplot2 (Wickham 2009). The work teams and the interactions between them were determined using the igraph package (Csardi and Nepusz 2006). All analyzes in this study were carried out using $\mathrm{R}$ version 3.3.3 ( $\mathrm{R}$ Core Team 2017) on the RStudio platform (RStudio Team 2015).

\section{Results}

Temporal Trend and Journals. A total of 188 articles were gathered: 1 book, 6 book chapters and 181 articles published between 1998 and 2017; 88.2 \% of these were published over the past 7 years (Figure 1). These articles were published in 50 journals: 9 national and 41 international journals; $76.1 \%$ were published in the journals Therya, Revista Mexicana de Biodiversidad, Acta Zoológica Mexicana (new series), Revista de Biología Tropical, Western North American Naturalist, The Souhtwestern Naturalist, Agroproductividad, Tropical Conservation Science, Revista Mexicana de Mastozoología, Oryx, Mammalia, and Animal Biology (Figure 2).

Authors. Articles were written by 406 co-authors from various Mexican and foreign institutions. According to their contribution, 28 authors published 5 or more articles, altogether accounting for $32.4 \%$ of all articles published (Fig-

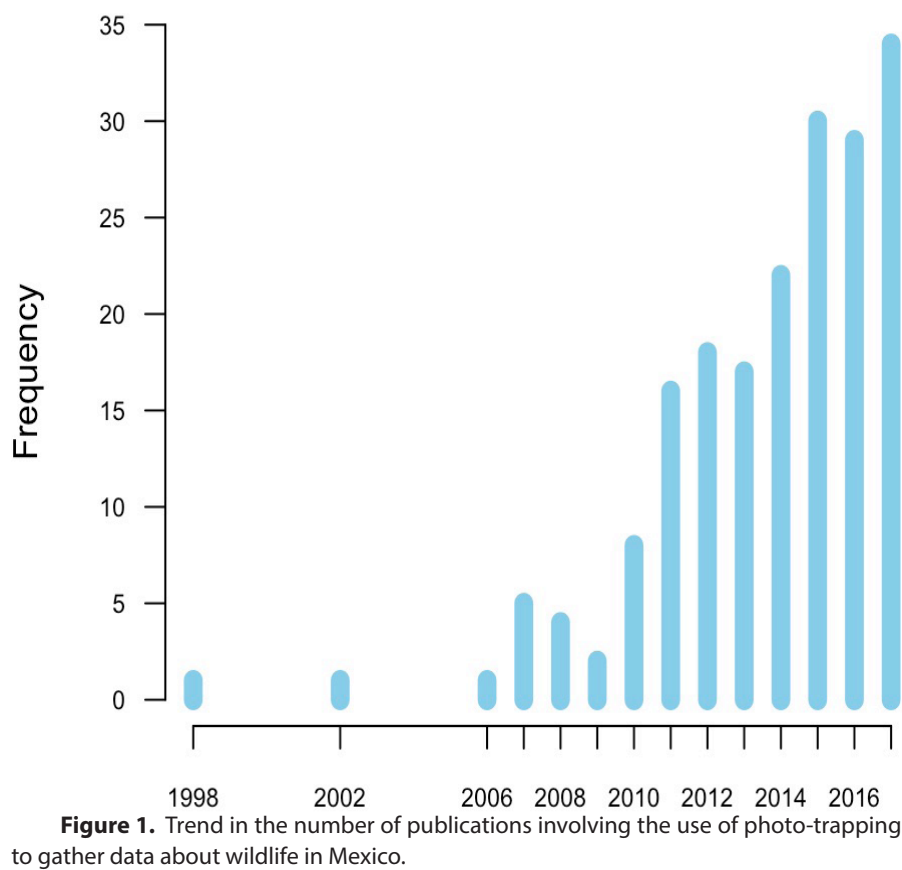




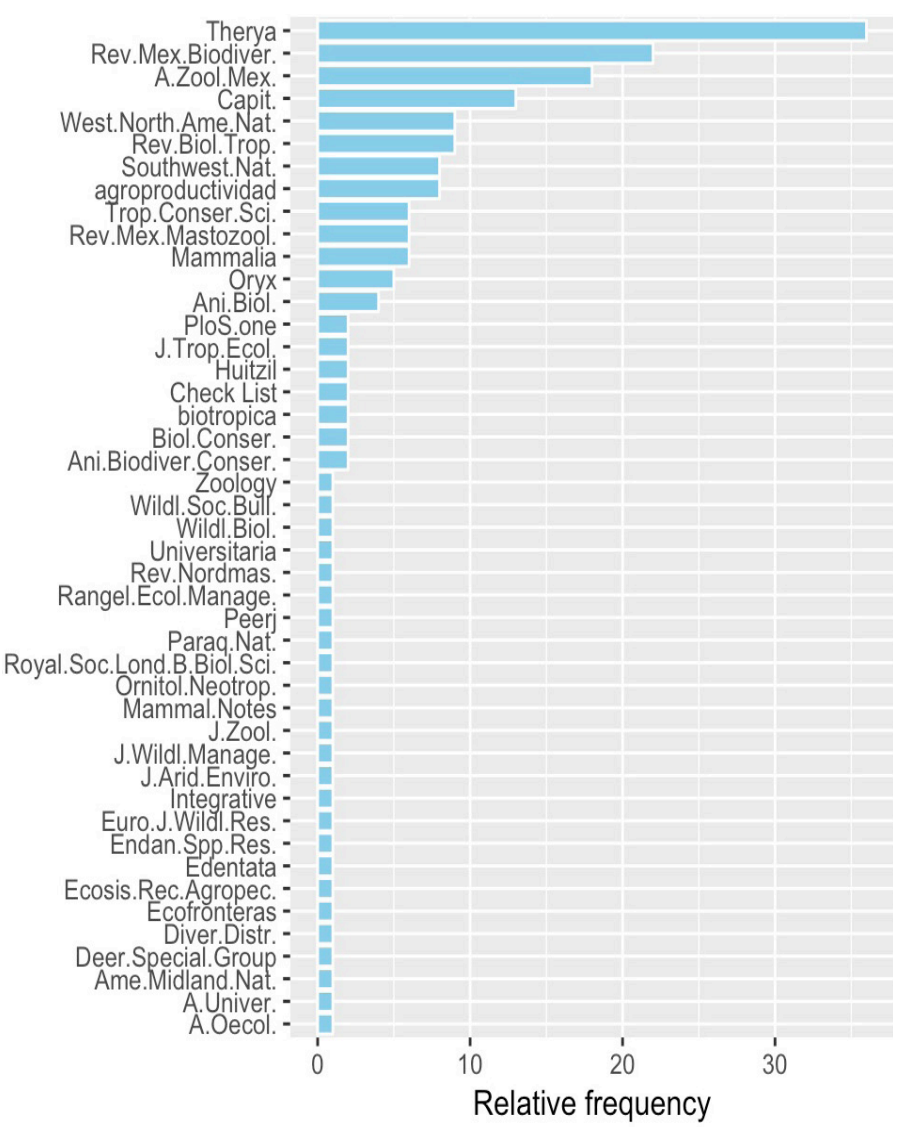

Figure 2. Journals that have published studies involving photo-trapping in Mexico. Abbreviations:

ure 3). This analysis yielded a relatively complex network of interactions between researchers (Figure 4). Research groups with some publications and little interaction with the rest are shown at the periphery of the network. In con-

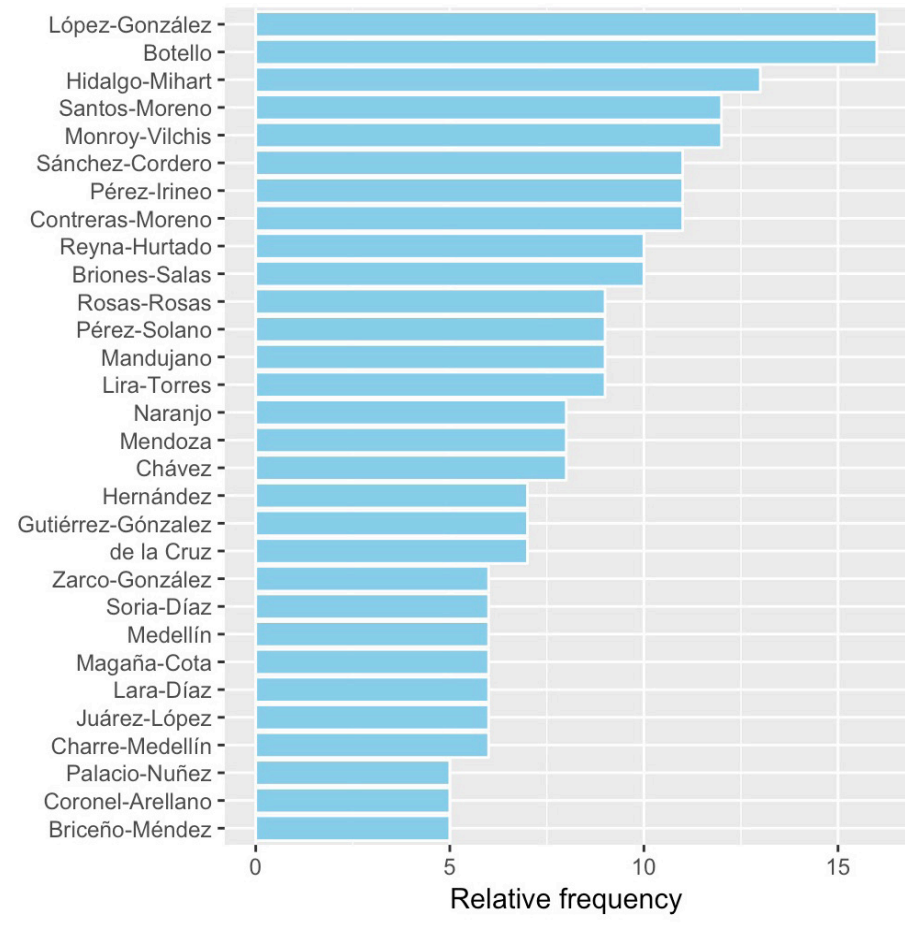

Figure 3. Main authors that have contributed a large number of publications involving photo-trapping in Mexico. Authors who have contributed more than two articles are shown.

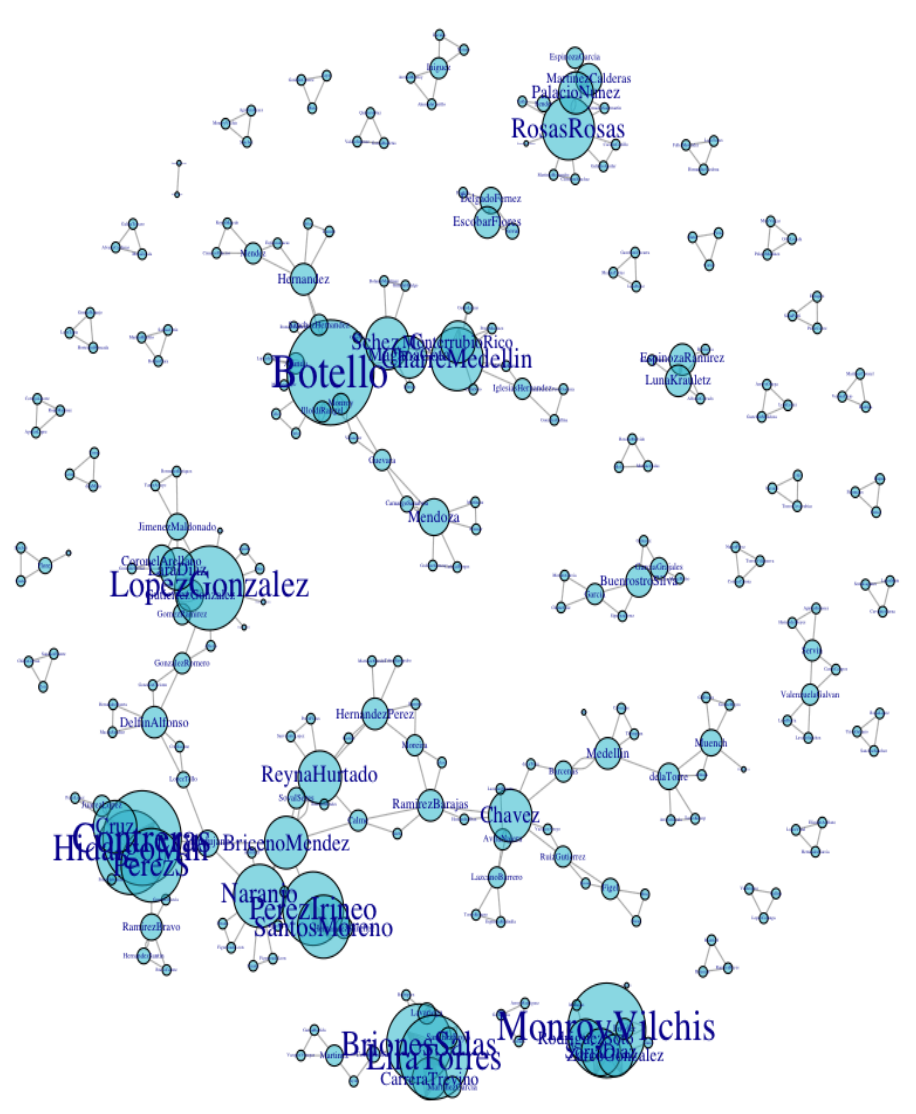

Figure 4. Interactions network between scientists who have used and published works involving photo-trapping in Mexico. The size of letters indicates the number of publications by a given author and the extent of his/her interactions with other coauthors.

trast, several clusters of work teams and their interaction with other groups appear to the center of the network. The major teams identified are: 1) Botello, Sánchez-Cordero, Charre-Medellín. 2) López-González, Lara-Díaz, CoronelArellano, Gutiérrez-González. 3) Hidalgo-Mirhart, Contreras-Moreno, de la Cruz, Pérez-Solano. 4) Reyna-Hurtado, Briceño-Méndez, Sandoval-Serés, Sanvicente-López. 5) Monroy-Vilchis, Soria-Díaz, Rodríguez-Soto. 6) RosasRosas, Tarango-Arambula, Clemente-Sánchez, PalacioNúñez, Hernández- SaintMartín. 7) Lira-Torres (r. i. p.), Briones-Salas. 8) Pérez-Irineo, Santos-Moreno. 9) Chávez, Ceballos. 10) Medellín, de la Torre.

Species. A total of 40 species are reported in the title or in the abstract of publications involving photo-trapping, with felines and ungulates as the main groups. Particularly, Panthera onca, Leopardus pardalis, Puma concolor, Tapirus bairdii, Tayassu pecari, Odocoileus virginianus, and Cuniculus paca account for $55.1 \%$ of articles (Figure 5).

Main Topics. Photo-trapping studies cover a diverse range of topics. Most frequently, studies report new records, that is, when a species is recorded photographically in a site for the first time ever (Figure 6). Occasionally, these new records broaden the geographical distribution range. In order of frequency, these are followed by studies that report the number of species (richness) in a particular site or region, and the estimated population size measured as the index of relative abundance (IAR), density, and 


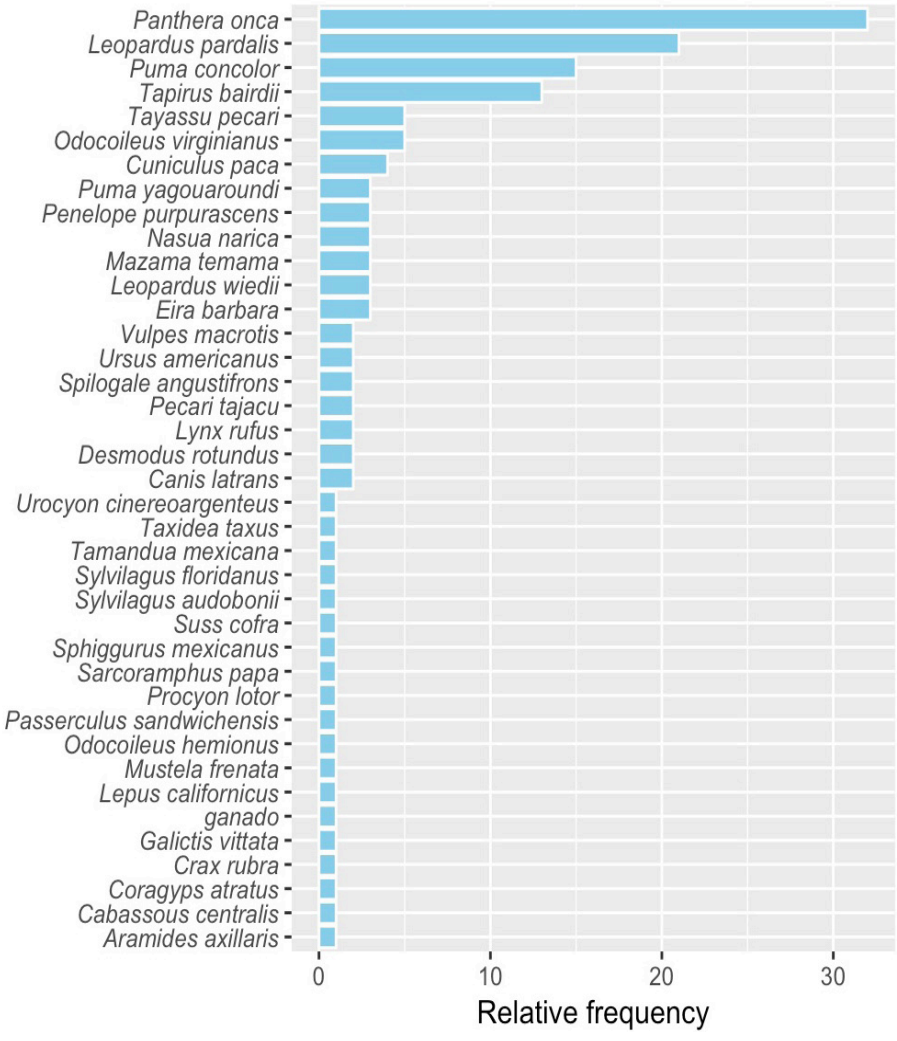

Figure 5. Species more frequently studied with photo-trapping in Mexico. Abbreviations:

occupancy, activity patterns, and ecological interactions including predator-prey, frugivory, and parasitism. Also, photo-trapping has served to gather presence data for subsequent modeling of the potential geographic distribution.

Regions, states, and natural areas. The regions with the largest number of studies using trap-cameras are located in the Southeast, followed by the Center; while fewer investigations have been conducted in the North (Figure 7a). In

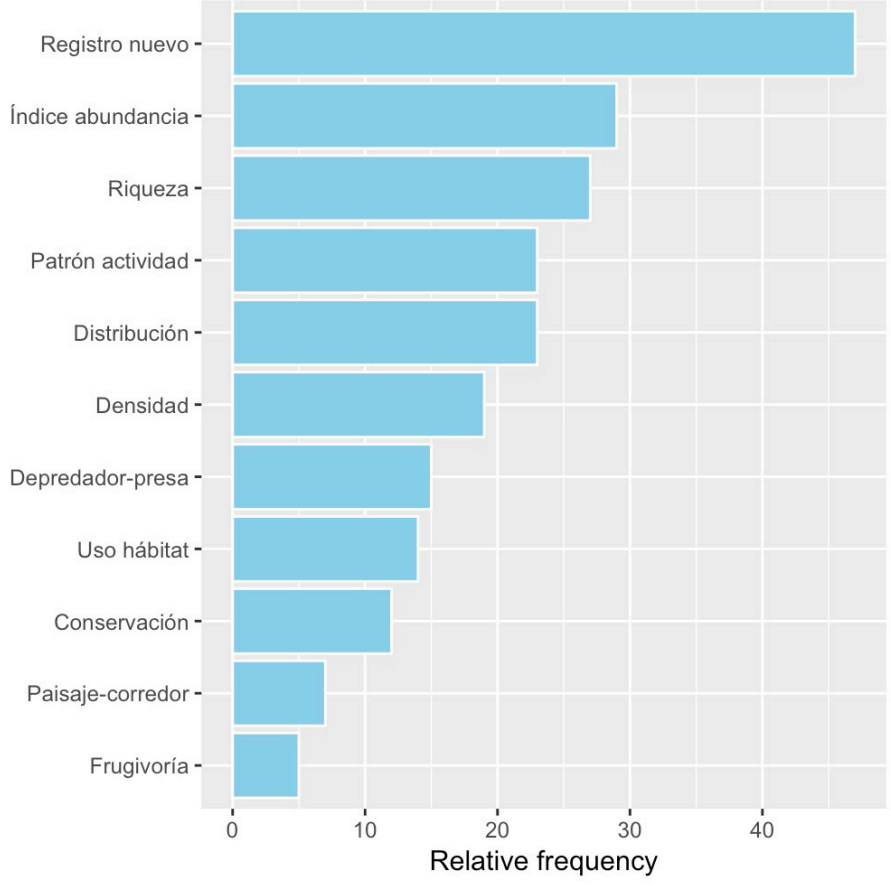
Mexico

Figure 6. Topics most frequently addressed in studies using photo-trapping in particular, Oaxaca is the state where the largest number of studies with this technology have been conducted, followed by Campeche, Sonora, Chiapas, Guanajuato, and Puebla, altogether accounting for $33.1 \%$ of the total number of published articles (Figure 7b). A fact worth mentioning is that many studies have been carried out within or near Biosphere Reserves, reserve areas and similar zones, such as Tehuacán-Cuicatlán, La Lacandona, Calakmul, Los Chimalapas, Sierra Gorda, Laguna de Terminos, Sierra Norte, the so-called Sky Islands, Nanchichitla, El Cielo, and the Chihuahuan Desert (Figure 7c).

a)

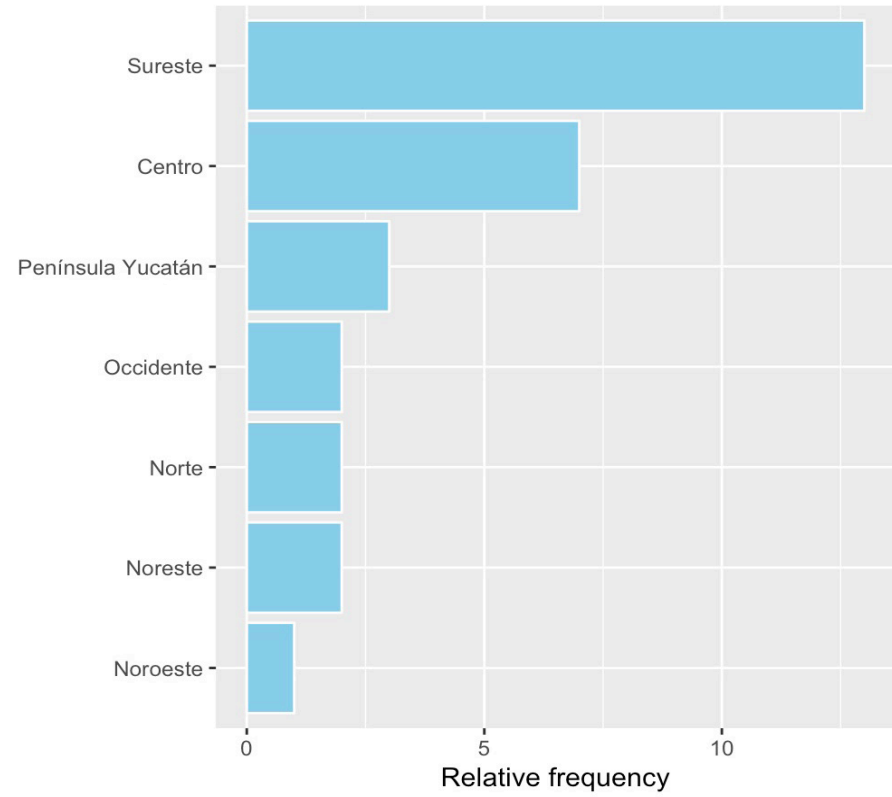

b)

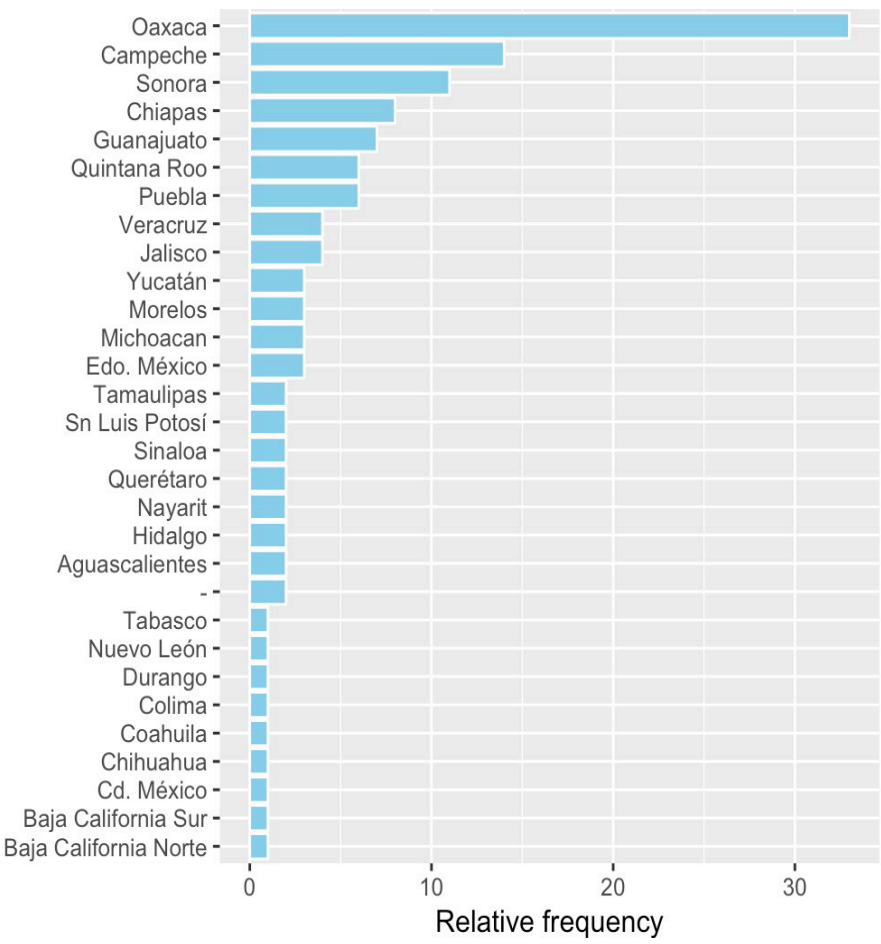

Figura 7. Regions (a), and states (b) , most frequently addressed in studies using photo-trapping in Mexico. 
c)

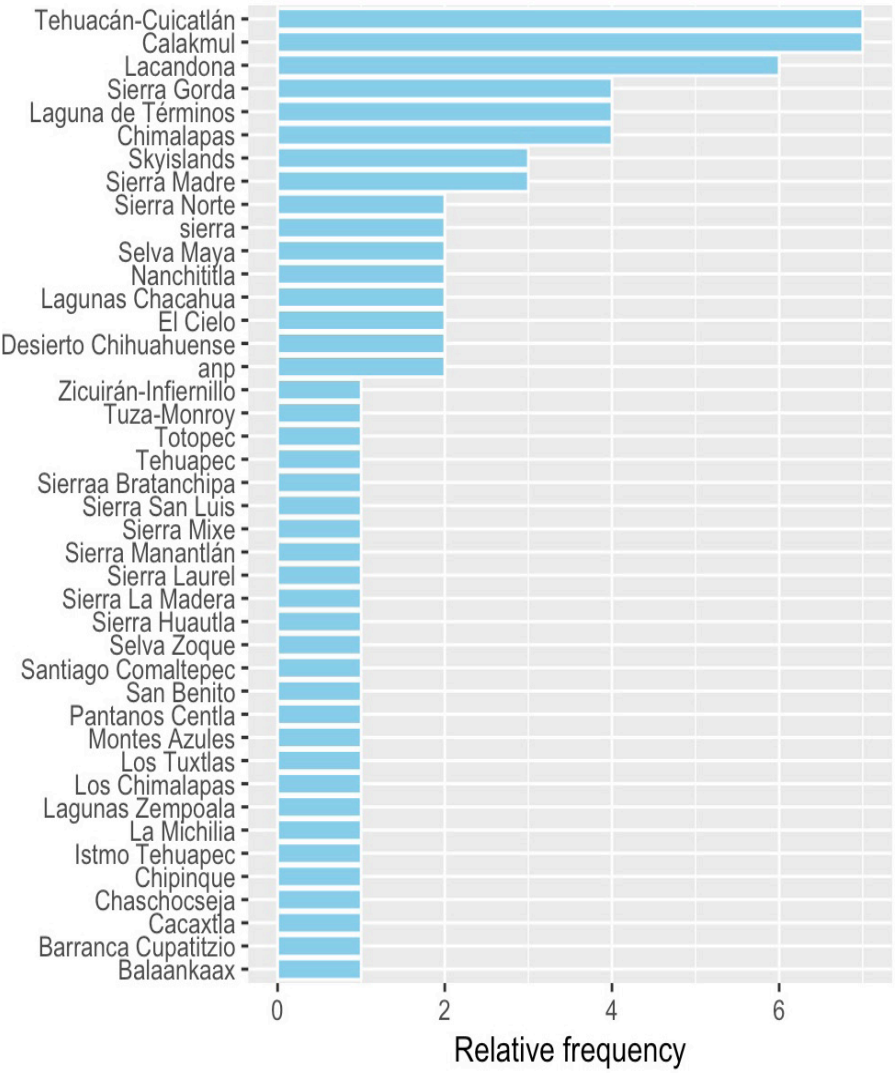

Figura 7c. Natural areas most frequently addressed in studies using photo-trapping in Mexico.

\section{Discussion}

The text mining analysis clearly indicates that the use of photo-trapping is on the rise in our country (Figure 8). Although this technique started being used since the late 1980s, it was until 1998 when the first article involving this technology in Mexico was published (Lopez-González et al. 1998). The use of this method escalated during the first decade of this century, and more than $88 \%$ of the works gathered here were published over the past siete years. This increase in the use of photo-trapping in Mexico mirrors the global trend (e. g., Rowcliffe and Carbone 2008). This is due to the fact that there is a growing number of scientists interested in using this technology. The data indicate that publications have been authored by more than 400 researchers; however, considering students, technicians, landowners and other persons that do not publish their findings in journals, this figure is probably even higher. Therefore, the number of published works using this technology is expected to increase significantly in the next few years. Studies using trap-cameras in Mexico have been published in various national and international journals, in addition to some chapters in books, and even in a book/ manual addressing practical aspects related to photo-trapping in the field (Chavez et al. 2013). Articles have been published mainly in Mexican scientific journals, a fact that highlights the importance and need to strengthen and project national journals at international levels by including them in high-impact indexes.
When the species referred to in the title or in the abstract of an article are used as the sole inclusion criteria in this analysis, the results clearly indicate that the species most frequently studied include felines (jaguar, ocelot and puma), ungulates (tapir, white-lipped peccary, and whitetailed deer), and several species of the order Carnivora. In particular, the most frequent investigations focus on the jaguar, as this is a charismatic species used as indicator of ecosystem health that is currently endangered (e.g., Chavez et al. 2013). On the other hand, although authors such as Botello et al. (2007) have suggested the use of phototrapping to gather data for birds and reptiles, in practice it has been used only partially for birds. However, as in other parts of the world (e. g., O'Brien and Kinnaird 2008), the number of published studies is expected to increase, since a number of investigations are ongoing that report the use of this technology to gather data on birds. To note, a single article published in Mexico used photo-trapping to obtain information from seed predation by a mouse (i. e., ChilpaGalv et al. 2017). This technology is already commonly used in other regions of the world to survey small mammals. As regards reptiles, no published studies were found involving the use of camera-traps, unlike other countries where this technique is already in use for highly conspicuous species (e. g., Bennet and Clements 2014). Although photo-trapping is an appealing technology, for many groups of animals it is not entirely suitable, as in the case of small mammals like rodents, bats, arboreal mammals, passeriform birds, and reptiles (McCallum, 2013, Rowcliffe 2017). For these taxonomic groups, the use of other methods remains as the best alternative; in this regard, camera-traps will only be a supplementary method, as shown by many of the works analyzed and cited herein. In addition, a high proportion of data have been obtained from sampling with cameras placed very close to the ground. This is worth stressing, as an important group of mammals and birds are arboreal; therefore, sampling designs that are suitable for this group of animals are required in their habitats (e. g., Gregory et al.

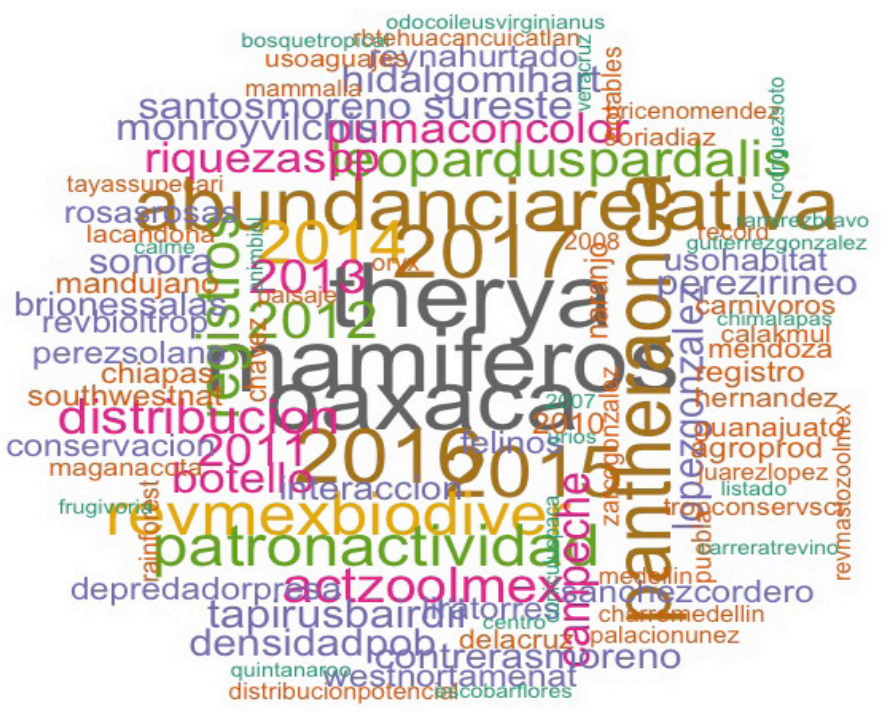

Figure 8. Cloud diagram illustrating photo-trapping in Mexico. 
2014). Although no published work addressing this issue was identified, a number of field investigations of arboreal mammals involving camera-traps in Mexico are ongoing.

Similar to other countries, photo-trapping has been used in Mexico to investigate a range of aspects about the biology of animal species. In terms of the number of works, the main topic of interest deals with new records of species in sites where there their presence had not been previously reported; a topic closely related to new records is the broadening of the geographic range. Likewise, photo-trapping is being used to record the presence of species as supplementary data for modeling the potential distribution range using the ecological niche theory as conceptual framework - a conceptual and methodological approach commonly used today. Another aspect frequently addressed is the study of species richness and diversity. In many cases, photo-trapping is employed as the only method to report species richness, particularly in the case of mediumsized and large species, which are the species most easily detected with this technique. Other studies have applied photo-trapping as a supplementary method along with traps, nets and traces, to elaborate lists of species in certain sites. In other words, photo-trapping is a key method in Mexico for broadening and contributing to the knowledge of biodiversity and distribution of animal species, mainly medium-sized and large mammals which, given their habits and rarity, are often hard to spot and for which data gathering is difficult when other sampling methods are used (Thompson 2013). Finally, some practical aspects worth stressing are, on the one hand, the systematization of images obtained by photo-trapping in record cards filed in Scientific Collections, which are key for the knowledge of diversity; on the other, the development and training in different techniques and methods of analysis associated with photo-trapping (Botello et al. 2007).

The study of population size, particularly the use of the so-called indices of relative abundance (IAR), is a topic frequently addressed in photo-trapping studies. Related to population size estimates, some works have focused on density through classical capture-recapture and, more recently, the so-called spatially explicit capture-recapture methods. In contrast, few studies have focused on estimating occupancy. Separately, numerical and statistical methods employed to analyze photo-trapping data have covered various approaches, ranging from the absolute subjective interpretation of the so-called indices of relative abundance (IAR) to very robust methods of analysis (Springer et al. 2012). The text mining analysis indicates that the IAR is still extensively used in our country despite its serious limitations (Sollmann et al. 2013).

In this respect, users of camera-traps in our country should apply a high statistical rigor in their analysis. Fortunately, the publication of works that estimate population size through capture-recapture and even spatially explicit methods is on the rise (e. g., Carbajal-Borges et al. 2014). These models require the recognition of individuals. When individual identification is not possible, there are several alternatives; one is the use of occupancy models (e. g., Cove et al. 2013) and the use of models that estimate density without the need to recognize individuals (e.g., Rowcliffe et al. 2014, Cusack et al. 2015, Rowcliffe et al. 2016). Also, the application of traditional distance-based methods (Thomas et al. 2010) for photo-trapping data is increasing (Rowcliffe et al. 2011, Howe et al. 2017). Another area of opportunity offered by camera-traps is video recording (Delgado-V. et al. 2011, McCallum, 2013, Rowcliffe 2017).

Camera-traps can record the time, temperature, moon phase and other data simultaneously with each image. This has the use of this technology to estimate the patterns of activity and the overlap of these patterns between species. In addition, photo-trapping has been used to analyze the use of the habitat. Although this application is not common yet, photo-trapping can be used to gather physiological information, in particular regarding reproduction (e.g., Aranda et al. 2012). Ecological interactions is another topic of growing interest, especially for predation-prey interactions, frugivory, and parasitism, through functional ecological (Soria-Díaz et al. 2017a, 2017b) and experimental (Camargo-Sanabria et al. 2015) approaches. In addition, photo-trapping studies are addressing not only the distribution and abundance of species, but also other aspects related to conservation, such as hunting, habitat fragmentation, and livestock raising, as well as the effect of hurricanes, landscape management and connectivity (e. g., LaraDíaz et al. 2013). In other words, photo-trapping is yielding very interesting findings on a number of topics related to behavior, interactions, and management.

Although camera-traps are being used across the country, data mining clearly evidenced that the majority of studies have been conducted in the Southeast region. In particular, Oaxaca stands out as the state with the largest number of published studies involving photo-trapping. Next in importance are Campeche, Chiapas, Quintana Roo, and Yucatan. In the center of the country, the states that yielded the largest number of publications are Guanajuato, Puebla, Veracruz, Michoacán and Jalisco. In the north, the state of Sonora is worth mentioning. Separately, a significant percentage of studies involving photo-trapping have been conducted in Protected Natural Areas, mainly Biosphere Reserves such as Tehuacán-Cuicatlán, La Lacandona, Calakmul, Los Chimalapas, Sierra Gorda, Laguna de Terminos, and Sierra Norte. The biosphere reserves share a vision of the integration of the various uses of resources consistent with the long-term conservation of biological and cultural diversity, under a land-use scheme based on core, buffer and transition zones. According to Halffter (2011), some reserves are associated with laboratories or institutions that have been pivotal research centers, producing abundant and important knowledge. In this sense, in addition to their key role in the creation of knowledge and prevention of changes of land use (Figueroa and Sánchez-Cordero 2008), ANPs frequently offer adequate conditions of personal safety and equipment used in photo-trapping studies. 
In Mexico, there are initiatives for the application of photograph collection and monitoring protocols at the country level, such as the biological photograph collection of UNAM (Botello et al. 2007), as well as programs promoted by the National Forestry Commission (CONAFOR) and the National Commission of Protected Areas (CONANP). There are also local and regional initiatives for the monitoring of wild animals using trap-cameras, such as the Community Monitoring of Biodiversity in Oaxaca, an appealing initiative that includes a user-friendly webpage (http://dsjm-conanpmonitoreo.org). Another example is the Proyecto Guerrero Jaguar social initiative for the monitoring of wildlife in the state of Guerrero (www.facebook.com/guerrerojaguar). In addition, monitoring programs of key species for conservation have been in place for several years; an example is the jaguar, a species for which photo-trapping has been a core method (Chávez et al. 2013). Likewise, meetings such as the First Meeting of Photo-Trapping Experts in Mexico organized by the National Commission for the Knowledge and Sustainable Use of Biodiversity (CONABIO) have as a key objective to integrate the information obtained from individual studies and programs involving photo-trapping. As a result, progress has been made in having monitoring protocols in place and, to the extent possible, homogenize data collection to facilitate comparisons between regions.

\section{Supplementary Material}

The complete list of bibliography compiled for the analyses in this article and the detailed text mining procedure in $\mathrm{R}$ used in this work are available from the author upon request.

\section{Cited literature}

Ahumada, J. A., C. E. F. Silva, K. Gajapersad, C. Hallam, J. Hurtado, E. Martin, A. McWilliam, B. Mugerwa, T. O'Brien, and F. Rovero. 2011. Community structure and diversity of tropical forest mammals: data from a global camera trap network. Philosophical Transactions of the Royal Society of London B: Biological Sciences 366:2703-2711.

Aranda, M., F. Botello, and L. López-de-Buen. 2012. Diversidad y datos reproductivos de mamíferos medianos y grandes en el bosque mesófilo de montaña de La Reserva de la Biosfera Sierra de Manantlán, Jalisco-Colima, México. Revista Mexicana de Biodiversidad 83:778-784.

Baillie, J. E. M., B. Collen, R. Amin, H. R. Akcakaya, S. H. M. Butchart, N. Brummitt, T. R. Meagher, M. Ram, C. Hilton-Taylor, and G. M. Mace. 2008. Toward Monitoring Global Biodiversity. Conservation Letters 1:18-26.

Bennett, D., And T. Clements. 2014. The use of passive infrared camera trapping systems in the study of frugivorous monitor lizards. Biawak 8:19-30.

Botello, F., G. Monroy, P. Illoldi-Rangel, I. Trujlllo-Bolio, and V. SÁnchez-Cordero. 2007. Sistematización de imágenes obtenidas por foto-trampeo: una propuesta de ficha. Revista Mexicana de Biodiversidad 78:207-210.

Bruner, A. G., R. E. Guluison, R. E. Rice, and G. A. B. Da Fonseca. 2001. Effectiveness of parks in protecting tropical biodiversity. Science 291:125-128.
Burton, A. C., E. Neilson, D. Moreira, A. Ladle, R. Steenweg, J. T. Fisher, E. BAYNE, AND S. BOUTIN. 2015. Wildlife camera trapping: a review and recommendations for linking surveys to ecological processes. Journal of Applied Ecology 52:675-685.

Camargo-Sanabria, A. A., E. Mendoza, R. Guevara, M. Martínez-Ramos, AND R. DiRzo. 2015. Experimental defaunation of terrestrial mammalian herbivores alters tropical rainforest understorey diversity. Proceedings of the Royal Society of London B: Biological Sciences 282:20142580.

Carbajal-Borges, J. P., O. Godínez-Gómez, and E. Mendoza. 2014. Density, abundance and activity patterns of the endangered Tapirus bairdii in one of its last strongholds in southern Mexico. Tropical Conservation Science 7:100-114.

Chávez, C., A. De la Torre, H. Bárcenas, R. A. Medellín, H. Zarza, and G. Ceballos. 2013. Manual de foto-trampeo para estudio de fauna silvestre. El jaguar en México como estudio de caso. Alianza WWF-Telcel, Universidad Nacional Autónoma de México. Ciudad de México, México.

Chilpa-Galván, Ch., G. Zotz, G. J. Sánchez-Fuente, C. EspadasManRiQue, J. L. Andrade, ANd C. Reyes-García. 2017. Drought, postdispersal seed predation, and the establishment of epiphytic bromeliads (Tillandsia spp.). Biotropica 49:770-773.

Cove, M. V., R. M. Spínola, V. L. Jackson, J. C. SÁenz, and O. Chassot. 2013. Integrating occupancy modeling and camera-trap data to estimate medium and large mammal detection and richness in a central American biological corridor. Tropical Conservation Science 6:781-795.

CSARDI, G., AND T. Nepusz. 2006. The igraph software package for complex network research. InterJournal Complex Systems:1695. http://igraph.org. June 24, 2015

Cusack, J. J., A. Swanson, T. Coulson, C. Packer, C. Carbone, A. J. Dickman, M. Kosmala, C. Lintott, and J. M. Rowcliffe. 2015. Applying a random encounter model to estimate lion density from camera traps in Serengeti National Park, Tanzania. Journal of Wildlife Management 79:1014-1021.

Delgado-V., C. A., A. Árias-Alzate, S. Botero, and J. D. SánchezLONDOÑO. 2011. Behaviour of the Eira barbara near Medellín, Colombia: preliminary data from a video-capturing survey. Small Carnivore Conservation 44: 19-21.

FEINERER, I., AND K. HORNIK. 2017. tm: text mining package. https:// CRAN.R-project.org/package=tm. July 29, 2018

FigueroA, F., AND V. SÁnChEZ-Cordero. 2008. Effectiveness of natural protected areas to prevent land use and land cover change in Mexico. Biodiversity and Conservation 17:3223-3240.

Fleming, P., P. Meek, G. Ballard, P. Banks, A. Claridge, J. Sanderson, And D. SWANn. 2014. Camera Trapping: Wildlife Management and Research. CSIRO Publishing. Melbourne, Australia.

Gregory, T., F. Carrasco Rueda, J. Deichmann, J. Kolowski, and A. Alonso. 2014. Arboreal camera trapping: taking a proven method to new heights. Methods in Ecology and Evolution 5:443-451.

Halffter, G. 2011. Reservas de la Biosfera: problemas y oportunidades en México. Acta Zoológica Mexicana 27:177-189. Howe, E. J., S. T. Buckland, M. L. Després-Einspenner, and H. S. KüHL. 2017. Distance sampling with camera traps. Methods in Ecology and Evolution 8:1558-1565.

Jenks, K. E., P. Chanteap, D. Kanda, C. Peter, P. Cutter, T. Redford, J. L. Antony, J. Howard, and P. Leimgruber. 2011. Using relative abundance indices from camera-trapping to test wildlife 
conservation hypotheses-an example from Khao Yai National Park, Thailand. Tropical Conservation Science 4:113-131.

KwartLer, T. 2017. Text mining in practice with R. John Wiley and Sons Ltd. Oxford, United Kindom.

Lara-Díaz, N. E., C. A. López-González, H. Coronel-Arellano, and A. GonZÁlEZ-BERnAL. 2013. Black bear population and connectivity in the Sky Islands of Mexico and the United States. Biological Conservation 144:263-268.

López-Gonzálezz, C. A., A. González-Romero, and J. W. Laundré. 1998. Range extension of the bobcat (Lynx rufus) in Jalisco, Mexico. The Southwestern Naturalist 43:103-105.

MATA-PÉREZ, M. 2014. Bibliografía en LATEX: una guía concisa de BibTEX. Version 0.4. http://logistica.fime.uanl.mx/miguel/ docs/BibTeX.pdf. October 11, 2014.

MCCALLUM, J. 2013. Changing use of camera traps in mammalian field research: habitats, taxa and study types. Mammal Review 43:196-206.

McLean, M.W. 2014. Straightforward bibliography management in $\mathrm{R}$ using the RefManager package. http://arxiv.org/ abs/1403.2036. March 9, 2014

McLean, M. W. 2017. RefManageR: import and manage BibTeX and BibLaTeX references in R. The Journal of Open Source Software 2:1-2

Meek, P. D., And A. Pittet. 2012. User-based design specifications for the ultimate camera trap for wildlife research. Wildlife Research 39:649-660.

O'Brien, T. G., AND M. F. KInNAIRD. 2008. A picture is worth a thousand words: the application of camera trapping to the study of birds. Bird Conservation International 18:S144-S162. O'Brien, T. G., J. E. M. Baillie, L. Krueger, And M. Cuke. 2010. The Wildlife Picture Index: monitoring top trophic levels. Animal Conservation 13: 335-343.

O'Connell, A. F., J. D. Nichols, and K. U. Karanth. 2010. Camera traps in animal ecology: methods and analyses. Springer, New York, U. S. A.

R CORE TEAM. 2017. R: a language and environment for statistical computing. Vienna, Austria: R Foundation for Statistical Computing. https://www.R-project.org/. July 2, 2018.

Rovero, F., and F. Zimmermann. 2016. Camera trapping for wildlife research. Pelagic Publishing Ltd., United Kindom.

Rovero, F., F. Zimmermann, D. Berzi, And P. Meek. 2013. Which camera trap type and how many do it need? a review of camera features and study designs for a range of wildlife research applications. Hystrix the Italian Journal of Mammalogy 24:148-156.

RowCLIFFE, M. J. 2017. Key frontiers in camera trapping research. Remote Sensing in Ecology and Conservation 3:107-108.

RowCLIFFE, J. M., AND C. CARBONE. 2008. Surveys using camera traps: are we looking to a brighter future? Animal Conservation 11:185-186.

Rowcliffe, M. J., C. Carbone, P. A. Jansen, R. Kays, and B. Kranstauber. 2011. Quantifying the sensitivity of camera traps: an adapted distance sampling approach. Methods in Ecology and Evolution 2:464-476.

Rowcliffe, J. M., C. Carbone, R. Kays, B. Kranstauber, and P. A. Jansen. 2014. Density estimation using camera trap surveys: the random encounter model. Pp. 317-324, in: P. Meek and P. Fleming (eds.), Camera trapping: wildlife management and research. CSIRO Publishing, Melbourne, Australia.
Rowcliffe, J. M., P. A. Jansen, R. Kays, B. Kranstauber, and C. Carbone. 2016. Wildlife speed cameras: measuring animal travel speed and day range using camera traps. Remote Sensing in Ecology and Conservation 2:84-94.

RSTUDIO TEAM. 2015. RStudio: integrated development environment for R. Boston, MA: RStudio, Inc. http://www. rstudio.com/. July 1, 2018.

SiLGE, J., AND D. Robinson. 2017. Text mining with R: a tidy approach. O' Reilly Media, Inc., California, U. S. A.

Sollmann, R., A. Mohamed, H. Samejima, and A. Wilting. 2013. Risky business or simple solution-relative abundance indices from camera-trapping. Biological Conservation 159:405-412.

SORIA-DiAZ, L., M. S. Fowler, O. Monroy-VILCHIS, AND D. Oro. 2017 a. Functional responses of cougars (Puma concolor) in a multiple prey-species system. Integrative Zoology 13:84-93.

SORIA-Díaz, L., M. S. Fowler, AND O. Monroy-Vilchis. 2017b. Topdown and bottom-up control on cougar and its prey in a central Mexican natural reserve. European Journal of Wildlife Research 63:1-10.

Springer, M. T., A. D. Carver, C. K. Nielsen, N. J. Correa, J. R. Ashmore, AND J. G. LEE. 2012. Relative abundance of mammalian species in a central Panamanian rainforest. Revista Latinoamericana de Conservación 3:19-26.

Thomas, L., S. T. Buckland, E. A. Rexstad, J. L. Laake, S. Strindberg, S. L. Hedley, J. R. B. Bishop, T. A. Marques, and K. P. Burnham. 2010. Distance software: design and analysis of distance sampling surveys for estimating population size. Journal of Applied Ecology 47:5-14.

Thompson, W. (Ed.). 2013. Sampling rare or elusive species: concepts, designs, and techniques for estimating population parameters. Island Press, Washington, U. S. A.

Wearn, O. R., and P. Glover-Kapfer. 2017. Camera-trapping for conservation: a guide to best-practices. WWF Conservation Technology Series 1(1). WWF-UK, Working, United Kingdom. WiскнAм, H. 2017. tidyverse: easily install and load. https:// CRAN.R-project.org/package=tidyverse. November 14, 2017. WICKHAM, H. 2009. ggplot2: Elegant graphics for data analysis. Springer-Verlag. New York, U. S. A.

Associated editor: Rafael Reyna

Submitted: Agust 24, 2018; Reviewed: October30, 2018;

Accepted:December 19, 2018; Published on line: January 25, 2019. 